\title{
Regional Aspect of Value Added Use in Assessing Competitiveness of Economic Districts
}

\author{
Kamalova A.A \\ Kazan Federal University, Institute of Management, Economics and Finance, Kazan, 420008, Russia \\ Email: kamalina@yandex.ru \\ Polovkina E.A.
}

Kazan Federal University, Institute of Management, Economics and Finance, Kazan, 420008, Russia

\section{Doi:10.5901/mjss.2014.v5n24p24}

\section{Abstract}

The article focuses on the methodology for assessing the competitiveness ranking of economic regions. Based on measuring the effectiveness of creating added value, methodological approaches to rating assessment of economic entities' competitiveness are also investigated. Here, it is important to identify the factors that influence competitiveness level of the economic regions. We calculated competitiveness ranking of districts of the Republic of Tatarstan on the basis of value added using the method of regression and analysis of variance.

Keywords: economic value added, competitiveness, competitiveness factors, the system of economic indicators, regression analysis.

\section{Introduction}

The system of indicators that characterize the company's activities in the framework of cost management is constantly updated [3]. With the introduction of modern information technologies and new ideas indicators are becoming more objective and complex.

Implementation of an economic value added (EVA) can improve the quality of the current economic analysis of economic entities, improve the system of business valuation and improve the management of enterprises as a whole [4].

At the corporate level, EVA is used for management decisions related to the formation of the capital structure of the company; determination of the optimal number of units and the products types; distribution of cash flow between departments (to maximize return to shareholders) [5].

At the departmental level EVA is used as a tool to set goals, formulate strategy and increase the responsibility of managers for those EVA elements, which are under their control [6].

EVA can help to assess the quality of management decisions [McIntyre E.,1999]. Positive dynamics of this indicator means that the company operates more efficiently than the market as a whole, that is, it is more attractive for investors, therefore, the market value of a company increases [7].

Value added can be used to assess the competitiveness of the economies of the territories [8].

Evaluation of competitiveness of economies territories entails a comprehensive and systemic nature of the study [9]. Comprehensive and systematic approach to the problem is a consistent solution of the following questions:

1) definition of aggregate economies of the territories in relation to which competitiveness ranking will be calculated;

2) selection of the factors affecting the competitiveness level of the economies of the territories;

3) collection of statistical data and their processing;

4) conducting regression analysis;

5) economic evaluation of the results.

The study to assess the competitiveness of the economies of the territories was carried out at the micro and macro levels using data from the statistical reporting of economic entities and district consolidated statistical reporting of the region. 


\section{Methods}

To calculate the competitiveness of the economies of the territories most applicable is the following method based on the value added for the first time used by Kresl P.K. and Singh B. [10]. They used a group of indicators summing which they determine the level of competitiveness of the city, namely the change in the total value added in industry, retail trade and the total cost of business services.

Kresl P.K. and Singh B proposed the concept of added value for the assessment of the competitiveness and the development of a rating for 24 largest American metropolitan statistical areas (excluding the special case of Washington, DC). The task was to explain this rating through testing the hypotheses and analyzing by regression methods.

With the help of this methodology it was possible to describe each city's economy in terms of its competitiveness and weak points, as compared with 23 other large urban economies of the United States, to assess the strategic indicators of the city and urban planning, and even suggest items that should be included in its strategic plan.

Competitiveness is not the aspect that can be measured directly; all you can do is to determine its nature and the extent of the shadow it, so to speak, casts [11]. With this in mind, the authors used an approach consisting in choosing a small set of variables that could be taken as indicators of the competitiveness of the city.

Kresl P.K. and Singh B proposed the following concept:

City competitiveness ranking $=(\Delta$ manufacturing value added, $\Delta$ retail sales and $\Delta$ revenue from business services) (1)

In analyzing the concept, the authors concluded that the competitiveness of the economic region is influenced by other factors, and came to the following conclusions: the competitiveness of the city is determined by both economic and strategic determinants.

Economic determinants are quantitative in nature, and the data can be obtained from a variety of statistical sources, strategic determinants are qualitative in nature and can only be obtained through the surveys and study of relevant local documentation. The authors were unable to collect data on the latter. However, they managed to present an analysis of the determinants of economic competitiveness of cities by the following equation:

$C C=-10,8+3,41 \times 1+0,0112 \times 2+4,24 \times 3-0,00175 \times 4+0,594 h 5+0,288 \times 6+0,513 \times 7+0,000094 \times 8(2)$

where CC - competitiveness of the city;

$\mathrm{X} 1$ - the growth of cash income per capital;

x2 - research centers / surplus market value;

x3 - increase in the share of firms with a staff of over 100 employees;

x4 - labor force with the degree higher than Bachelor of Science / Arts;

$x 5$ - the share of engineering, administrative, research and management personnel in the total labor force;

$x 6$ - increase in the number of cultural institutions;

$x 7$ - growth of fixed capital for the state;

$\mathrm{x} 8$ - exports as a share of total production.

The obvious advantage of Kresl P.K. and Singh B approach is that the management of the economic region may obtain empirically informed, objective understanding of their competitive advantages and disadvantages, and that the urban economy can be evaluated in comparison to other urban economies with which it may compete for carrying out various economic activities.

\section{Discussion}

As for the assessment of economic competitiveness of the territory (city, district, region) currently a number of techniques based on the measurement of different factors and different systems of economic indicators operates. For example, as the main factors determining the competitiveness of an economic entity, M. Porter (monograph "Competition", 2002) calls parameters of factors (natural resources, skills, capital, infrastructure, etc.), demand conditions (level of income, elasticity of demand, demanding customers, etc.), related and supporting industries (level of education, banking, information, insurance services and other industries), strategy, structure and rivalry between firms (the level of competition between enterprises and industries) [12].

C.Jensen-Butler's concept, for example, highlights the factors such as the sectoral structure of the economy of the territory, the level of innovation, the value of the territory from the decision-making point of view, the level of skilled labor, the class structure and the degree of social well-being, the role of the territory as a cultural, educational and tourist center, the development of means of communication, the level of income and employment [13].

The concept of productivity by I. Begg considers gain in productivity, employment (use of human resources), the 
standard of living [10]. When evaluating competitiveness Huovari J., Kangasharju A., Alanen A. offer to analyze the level of human capital, innovation factors, local factors, factors of accessibility [14].

M. Parkinson's concept is based on factors such as economic diversification, workforce skills, the relationship of industry, education, science and politics, living standards, social and cultural environment, communication networks, the level of control [11].

There are also other approaches. L.Van den Berg, in particular, uses the following indicators: economic efficiency indicators, indicators of organizational capacity, local performance [15]. Concept by I. Bramezza involves the study of structural factors (effective infrastructure, municipal services, quality of life, effective urban policy) and functional factors (functions of the city as a center of competence) [16].

Many scholars point out that the territory can not be competitive in all sectors of the economy. Its wealth depends on its ability to attract or create sufficiently profitable economic activities. No territory may be most attractive for all kinds of economic activities, and the success in the competition is connected with the development of those where a specific city (district, region) has a competitive advantage. This suggests the need for some degree of territorial specialization in certain economic functions and their complementarity.

It should be noted that other researchers (Peter Morici, 1988 .; Michael Porter, 1990 .; Bruce Scott and George Lodge, 1985) have focused on the nation as the object of analysis and placed success of international trade in the center of their analysis [18], [19] , [20]. Data on international trade for the cities are often not available, but, what is more important in the study of urban (regional) economy is that internal competitiveness is as important as international one.

\section{Results}

Based on the methodology by Kresl P.K. and Singh B we calculated competitiveness ranking of districts of the Republic of Tatarstan, a part of the Russian Federation, on the basis of value added by the method of regression and analysis of variance. It should be noted at once that identification of all indicators that are listed in the methodology by KresI P.K. and Singh B turned out to be impossible due to the lack of complete statistical data on competitiveness factors of the republic's regions [9]. Therefore, available information was analyzed, which enabled to make certain conclusions about competitiveness ranking of the districts of the Republic of Tatarstan and about the influence of factors which determine the dynamics of competitiveness.

The method of regression analysis was applied for calculations, which is based on the establishment of relationships between variables in estimated parameters. To calculate the parameters of the multiple regression, Multiple Regression procedure with SPT Statgraphics was used.

As the parameters of competitiveness $(Y)$ were considered data on actual cash income $(X 1)$, the number of cultural institutions (X2) (number of libraries, institutions, culture and leisure, and film projectors), and investments in fixed assets (X3) in the districts of the RT for 2007-2013.

Data analysis allowed us to establish competitiveness ranking of the districts of the Republic of Tatarstan and its dynamics from 2007 to 2013. First of all, it should be noted that a number of districts observe the same tendency as in the study by Kresl P.K. and Singh B. concerning the regions of the United States, namely in the selected areas with the highest rating for 2007 - 2013 it decreases, while in the cities with the lowest rating it increases [9].

Stable first three places belong to Tukaevsky, Almetyevsk and Nizhnekamsk regions of RT. A number of districts have a relatively constant position in the ranking of competitiveness. The rating of individual RT districts changed during the calculation period significantly. So, in 2007 Aznakaevsky district had a rating of 4, while in 2010 and 2011 - 23, in 2012 - 9, in 2013 - 12 These results suggest that the competitiveness of the regional economy has been affected by the factors that are not included in the range of design variables, and fixed investment, growth of real monetary income and the change in the number of cultural institutions, which were considered in the study, are irrelevant competitiveness factors in the district. This is evidenced by the value of $F=0,193104604$, and $t$, which in the variables $X 1, X 2$ and $X 3$ has a very small value $(-0.446243882,0.548822561$ and -0.181252971 respectively), which characterizes the small correlation ratio between these variables and the final value of the region's competitiveness. This suggests that for a more reliable calculation of the competitiveness ranking it is necessary to expand the number of factors studied.

This method makes it possible to identify those factors that have the most influence on the competitiveness of the region. T-statistics indicates the degree of influence of factors $\mathrm{X} 1, \mathrm{X} 2$ and $\mathrm{X} 3$ on the final value of the competitiveness $\mathrm{Y}$. For each district of the RT one can determine which factor has the greatest value and, accordingly, which - the least. 


\section{Conclusion}

Detailed analysis of the data allows us to represent the situation of the combined effect of economic factors when creating added value in the districts of the republic. Such an analysis can be used further by district heads and their subordinates to make decisions in setting out priorities in social and economic development of regions. This requires improving the statistical base, which would allow for a more complete analysis of the competitiveness of the regions and cities of the country, taking into account the whole range of factors.

The notion of competitiveness which is traditionally reserved for use in connection with either national economy, or companies, is appropriate in relation to the economic regions, and their leaders can use this concept to guide the development of specific local economies [21, 23]. This can be done most effectively if the approach is both empirical and comparative. Management may determine the competitiveness of their economic region in relation to other competing economic ones and can also reveal its comparative strengths and weaknesses with a relatively objective methodology. Using the methods of regression and analysis of variance it is revealed which factors discussed in the research literature and in the popular press, in fact, are important to determine the competitiveness of the economic region. The result has been to show how the leaders of the economic region can use all this information when it is time to evaluate their past planning work and time to develop a strategic plan to improve the competitiveness of the economic region.

\section{References}

Damodaran A., 1999, "The Dark Side of Valuation: Firms with no Earnings, no History and no Comparables", Stern School of Business.

Li, T., Wang, C., 2010. The study on application value of EVA in enterprise perfomance evaluation. Proceedings of the International Conference on E-Business and E-Government. May 7-9, ICEE, Guangzhou, China, pp. 5331-5334.

Marganova R.R., Skipin D.L., 2014. Problems and prospects of EVA use in Russian practice of analyzing financial results/ Master's reporter.\# 5-3 (32). P. 90-93

Stewart B., 1991. The Quest For Value: a Guide for Senior Managers. - New York: Harper Collins Publishers.

Osipov Ya.I., 2011. Financial strategy of the company and EVA model. Russian entrepreneurship. \# 9-1. P. 66-71.

Lozhkina S.L., 2011. Prospects of EVA use in strategic management accounting. Reporter of the Bryansk State University. \# 3. P. 285291.

McIntyre E., 1999. Accounting choices and EVA. Business Horizons. \#1.

Cheryomushkin S.V., 2009. Interconnection between economic value added and market value of the company: criticism of EVA. Financial management. \# 4. P. 106-126.

Kresl P.K., Singh B., 2012. Urban Competitiveness and US Metropolitan Centres . Urban Studies, 49(2): 239-254.

Begg I., 2002. Investability: The Key to Competitive Regions and Cities? Regional Studies, 36(2), 187-200.

Parkinson M. 1996. The rise of the European entrepreneurial city. In: Financing of cities and regions: subsidiary and finance potentials. East-West conference, Munich, October.

Porter M.E., Kramer M.R., 2002. The competitive advantage of corporate philanthropy. Harvard business review. 80 (12), pp. 56-68, 133.

Jensen-Butler C., 1997. Competition between cities, urban performance and the role of urban policy: a theoretical framework. European cities in competition. Edited by C. Jensen-Butler, A. Shachar and J. van Weesep. - Avebury: European science foundation.

Huovari J., Kangasharju A., Alanen A., 2001 Constructing an index for regional competitiveness. Pellervo Economic Research Institute Working Papers. \#. 44, June.

Van den Berg L., Braun E. and van den Meer J., 1996. Organizing and Implementing Major Metropolitan Projects, European Regional Science Research Association 36-th European Congress, Zurich.

Bramezza I., Klink H.A., , 1994. Urban Management. Backgrounds and Concepts. — Rotterdam: EURICUR.

Mukhametshina G.R., Bulatov A.N., Antonova N.V.Methods to Provide Supply and Demand Balance on the Regional Industrial Labour Market (By Qualifications) // Mediterranean Journal of Social Sciences.- Vol.5, No12, (2014)-pp.145 - 148.

Morici, P. ,1988. Reassessing American Competitiveness. Washington, DC: National Planning Association.

Scott, B. and Lodge, G. C. (Eds), 1985. U.S. Competitiveness in the World Economy. Boston, MA: Harvard Business School Press.

Porter, M., 1990. The Competitive Advantage of Nations. New York: The Free Press.

Bulatov A.N., Mukhametshina G.R., Gazizullina A.R., Toropova N.V. The Role of the Project "Enterprise Factory" in the Competitiveness Recovery of the Regional Economy of the Republic of Tatarstan// Mediterranean Journal of Social Sciences.- Vol.5, No12, (2014)-pp.141 - 144.

Bausch A., Hunoldt. M., Matysiak.L., 2010. Superior performance through value-based management. (Book Chapter), pp. 15-36.

Dehning B., Kilic-Bahi S., Stratopoulos T., 2003, "The Firm Value Framework: A Unified Theory of Strategy". 